\title{
Effect of DNMT3A polymorphisms on CpG island hypermethylation in gastric mucosa
}

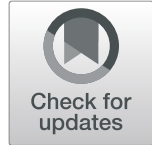

\author{
Hikaru Takano', Tomoyuki Shibata², Masakatsu Nakamura', Naoko Sakurai' ${ }^{1}$, Tasuku Hayashi ${ }^{1}$, Masafumi Ota', \\ Tomoe Nomura-Horita', Ranji Hayashi', Takeo Shimasaki ${ }^{1}$, Toshimi Otsuka', Tomomitsu Tahara ${ }^{3}$ and \\ Tomiyasu Arisawa ${ }^{1 *}$ (D)
}

\begin{abstract}
Background: $\mathrm{CpG}$ methylation of tumor suppressor genes occurs in the early stage of carcinogenesis. Detecting risk factors for aberrant CpG methylation is clinically important for predicting cancer development. DNA methyltransferase (DNMT) 3a is considered to play critical roles in the DNA methylation process during pathogenesis. In this study, we evaluated the association between DNMT3A polymorphisms (rs6733868 and rs13428812) and CpG methylation status in non-cancerous gastric mucosa.
\end{abstract}

Methods: We determined the DNMT3A genotype and CpG methylation status of 4 genes ( $p 14^{\text {ARF }}$, p16 $6^{\text {INK } 4 a}$, DAPK, and $(\mathrm{DH} 1)$ in 510 subjects without gastric cancer. Helicobacter pylori (HP) infection status was determined by the rapid urease test, urea breath test, speculum examination, or serum antibody test. We determined the DNMT3A genotype using polymerase chain reaction single-strand conformation polymorphism (PCR-SSCP). CpG methylation status was determined by methylation-specific polymerase chain reaction (MSP). When the methylated band was stronger than $10 \mathrm{ng} / \mu \mathrm{L}$ according to the DNA marker, we judged $\mathrm{CpG}$ island hypermethylation $(\mathrm{ClHM})$ to be present. Associations between genotypes and susceptibilities were assessed by logistic regression analysis.

Results: The minor allele frequencies of both polymorphisms (rs6733868 and rs13428812) were lower in the CpG methylated groups of each of the 4 genes $\left(p 14^{A R F}, p 16^{I N K 4 a}, D A P K\right.$, and $\left.C D H 1\right)$. Using a dominant genetic model, rs6733868 was significantly associated with the hypermethylation of each gene, whereas rs 13428812 was associated with the methylation of 3 genes (all except p14 $4^{A R F}$ ). When low-CIHM was defined as 1 or 2 CpG islands methylated and high-CIHM was defined as 3 or more CpG islands methylated, carrying the minor allele of rs6733868 was associated with both decreased low- and high-ClHM, and that of rs13428812 also was associated with a decrease. Comparing low-CIHM with high-ClHM, carrying the minor alleles of rs6733868 or rs 13428812 was related to decreased susceptibility to high-CIHM. In HP-infected subjects, carrying the minor alleles of rs6733868 or rs 13428812 had a significantly greater association with decreased susceptibility to high-CIHM.

Conclusions: Our study indicates that polymorphisms of DNMT3A are associated with the accumulation of gene methylation in gastric mucosa. Carrying the minor alleles of rs6733868 or rs 13428812 inhibits aberrant gene methylations, which are typically enhanced by HP infection.

Keywords: DNMT3A, Genetic polymorphism, CpG island, Hypermethylation, Gastric mucosa

\footnotetext{
* Correspondence: tarisawa@kanazawa-med.ac.jp

'Department of Gastroenterology, Kanazawa Medical University, 1-1 Daigaku, Uchinada-machi, Ishikawa 920-0293, Japan

Full list of author information is available at the end of the article
}

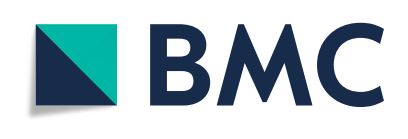

(- The Author(s). 2020 Open Access This article is licensed under a Creative Commons Attribution 4.0 International License, which permits use, sharing, adaptation, distribution and reproduction in any medium or format, as long as you give appropriate credit to the original author(s) and the source, provide a link to the Creative Commons licence, and indicate if changes were made. The images or other third party material in this article are included in the article's Creative Commons licence, unless indicated otherwise in a credit line to the material. If material is not included in the article's Creative Commons licence and your intended use is not permitted by statutory regulation or exceeds the permitted use, you will need to obtain permission directly from the copyright holder. To view a copy of this licence, visit http://creativecommons.org/licenses/by/4.0/ The Creative Commons Public Domain Dedication waiver (http://creativecommons.org/publicdomain/zero/1.0/) applies to the data made available in this article, unless otherwise stated in a credit line to the data. 


\section{Background}

Gastric cancer is one of the most common and deadly malignancies in the world. In 2018, gastric cancer was ranked as the fifth most commonly diagnosed cancer globally, and gastric cancer deaths accounted for $8.2 \%$ of all cancer deaths. Gastric cancer is thus the third leading cause of death from cancer. Additionally, more than 50\% of gastric cancers occur in eastern Asia [1]. Despite the declining trend in Japan due to insurance coverage to eradicate Helicobacter pylori (HP), gastric cancer remains a clinically significant malignancy, affecting 50, 000 people annually. It has long been known that HP infection is a risk factor for gastric cancer [2, 3], and it has been suggested that three steps are involved in gastric cancer progression: HP infection, the development of a precancerous state of the stomach, and carcinogenesis [4]. Correa proposed an oncogenic sequence in which differentiated gastric cancer (intestinal type) develops from HP infection through chronic gastritis (atrophic gastritis, intestinal epithelialization) [5]. Therefore, it has been recognized that advanced atrophic gastritis and intestinal epithelialization are essential conditions of the precancerous stage of gastric cancer from both morphological and histological perspectives [6].

From a molecular biological perspective, however, Maekita et al. found that the accumulation of abnormal DNA methylation in the gastric mucosa is critical for the precancerous state [7]. We also obtained the same results [8]. Methylation at CpG islands is a key mechanism of gene silencing, and there are known aberrant methylations occurring in specific genes in a variety of cancers, including gastric cancer $[9,10]$. Among the three known DNA methyltransferases (DNMTs), DNMT3a and DNMT3b are de novo DNMTs and are critical enzymes that cause dynamic DNA methylation during embryogenesis and pathogenesis [11]. In addition, overexpression of DNMTs has been observed in gastric carcinoma and nonneoplastic tissues susceptible to gastric carcinoma [12]. These facts suggest that $\mathrm{CpG}$ island hypermethylations (CIHM) caused by DNMTs might be crucial in the development of gastric cancer.

While HP infection is involved in the development of gastric cancer, the genetic constitution of an individual might also be involved, as gastric cancer does not occur in all HP-infected individuals. El-Omar and coworkers were the first to report that a genetic polymorphism of interleukin-1 $\beta$ is implicated in gastric cancer [13]. In our previous study, we demonstrated a relationship between gene polymorphisms of specific genes and gastric cancer susceptibility $[14,15]$. Despite the involvement of rs1550117, a known representative polymorphism of DNMT3A reported in various carcinomas, its role in gastric cancer is still controversial, particularly in Japanese patients [16]. Recently, we found that rs6733868 C>G and $\operatorname{rs} 13428812 \quad A>G$ of
DNMT3A are involved in HP infection, the progression of gastric mucosal atrophy, and gastric cancer susceptibility in a Japanese population [17]. However, the involvement of these DNMT3A gene polymorphisms in the accumulation of aberrant $\mathrm{CpG}$ methylation in the gastric mucosa has not been clarified.

We sought to elucidate the effects of DNMT3A polymorphisms rs6733868 and rs13428812 in the accumulation of $\mathrm{CpG}$ methylation in the gastric mucosa and how $\mathrm{HP}$ infection might impact the process.

\section{Methods \\ Population samples}

The study population comprised 510 subjects without cancer who attended the Endoscopy Center of Fujita Health University Hospital from January 2006 to December 2012. In all of the study participants, an upper gastrointestinal endoscopy was performed as a part of a health check-up, as a secondary examination following barium X-ray gastrography, or for any symptoms of abdominal discomfort. Of these, 402 were subjects recruited from our previous research [18]. Our exclusion criteria included: subjects with severe systemic diseases or malignancies of the stomach or other organs and any participant with a history of abdominal surgery or $\mathrm{HP}$ eradication. The study protocol was approved by the Ethics Committee of Fujita Health University School of Medicine, Japan, and written informed consent was obtained from all participants.

For each subject, biopsy samples were taken from the antrum at the time of endoscopy, and one part of each was immediately frozen and stored at $-80^{\circ} \mathrm{C}$ until use. Peripheral blood was collected at the time of endoscopy, and serum was prepared and frozen at $-80^{\circ} \mathrm{C}$. HP infection was determined when at least one of the following tests was positive: 1) rapid urease test, 2) urea breath test, 3) speculum examination, or 4) serum antibody test. Two tumor suppressor genes with methylation associated with aging and HP infection $\left(p 14^{A R F}\right.$ and $p 16^{I N K 4 a}$, respectively), death-associated protein kinase (DAPK), and E-cadherin $(C D H 1)$ were selected as candidates for the evaluation of CIHM [7, 17, 18]. Both p14 $4^{\mathrm{ARF}}$ and p16 ${ }^{\text {INK4a }}$ are translated from $C D K N 2 A$ by alternative splicing $[19,20]$. These four genes were selected because increased CpG island hypermethylation in these genes in non-neoplastic gastric mucosa has been shown to correlate with a higher risk of gastric cancer [21].

\section{Genotyping}

Genomic DNA was extracted from a portion of the frozen samples using proteinase K. In 408 cases, genomic DNA was extracted from blood samples. Genotyping was performed by the previously described polymerase chain reaction (PCR)-single-strand conformation polymorphism 
(SSCP) method [22]. The following primer sets were used: for rs6733868: forward, 5' -ctagctagcgggagtcgctgtc-3' and reverse, $5^{\prime}$-ctcctggctgtgaagcggaag-3'; for rs13428812: forward, 5'-ccccatcatgtcagataccctctg-3' and reverse, 5'ccttcctaggggacacccttctatt- $3^{\prime}$.

PCR was performed using EX Taq HS (Takara Bio, Shiga, Japan), adding $0.1 \mu \mathrm{g}$ of genomic DNA to $20 \mu \mathrm{L}$ of buffer, denaturing at $95^{\circ} \mathrm{C}$ for $3 \mathrm{~min}$, followed by $35 \mathrm{cy}$ cles of $15 \mathrm{~s}$ at $96^{\circ} \mathrm{C}, 30 \mathrm{~s}$ at $61{ }^{\circ} \mathrm{C}$, and $30 \mathrm{~s}$ at $72{ }^{\circ} \mathrm{C}$, and a 5-min final extension at $72{ }^{\circ} \mathrm{C}$. The same PCR conditions were used for rs6733868 and rs13428812. Then, $2 \mu \mathrm{L}$ of the PCR product was treated in $10 \mu \mathrm{L}$ of formamide for $5 \mathrm{~min}$ at $90^{\circ} \mathrm{C}$ and denatured to single strands. SSCP was performed with the Gene Phor DNA separation system using the Gene Gel Excel 12.5/24 kit (GE Health Care Bio-Sciences AB, Stockholm, Sweden) at a constant temperature of $18{ }^{\circ} \mathrm{C}$, and the denatured bands were detected using a DNA silver staining kit (GE Health Care Bio-Sciences AB).

\section{Bisulfite reaction and methylation-specific PCR (MSP) methods}

To detect DNA methylation, genomic DNA extracted from biopsy tissues was treated with sodium bisulfite using a BislFast DNA Modification Kit for Methylated DNA Detection (Toyobo, Osaka, Japan). The methylationspecific PCR (MSP) reaction was performed as previously described $[8,18]$. The primer sets used are shown in Table 1. Using EX Taq HS (Takara Bio, Shiga, Japan), PCR was performed for $0.1 \mu \mathrm{g}$ of bisulfite-modified DNA in $20 \mu \mathrm{L}$ of buffer with an initial denaturing step of $5 \mathrm{~min}$ at $95^{\circ} \mathrm{C}$, followed by $33-35$ cycles of $30 \mathrm{~s}$ denaturing at $95^{\circ} \mathrm{C}, 1 \mathrm{~min}$ annealing at $57-69^{\circ} \mathrm{C}$, and $1 \mathrm{~min}$ extension at $72{ }^{\circ} \mathrm{C}$, and a final 5 -min extension step at $72{ }^{\circ} \mathrm{C}$. $2.5 \%$ agarose gel electrophoresis was performed using $10 \mu \mathrm{L}$ of PCR product, stained with ethidium bromide, and visualized by UV illumination. The presence of CIHM was judged when the signal of the electrophoresis-separated positively-methylated band was stronger than that of the size marker (10 ng/ $\mu \mathrm{L}$ : 100 bp DNA Ladder; Takara Bio), regardless of the presence of unmethylated bands [23].

\section{Statistical analysis}

Hardy-Weinberg equilibria were assessed by the $x^{2}$ test. Mean age was expressed as mean \pm SD and analyzed using Student's $t$ test. HP infection rate and sex ratio were compared using Fisher's exact test. Genotype distribution and allele frequency were also assessed using Fisher's exact test. Odds ratios (OR) and 95\% confidence intervals (CI) for the extent of genotype involvement in DNA methylation were calculated using logistic regression analysis adjusted for sex, age, and HP infection status. The relationship between the number of genes with CpG methylation and genotype or HP positivity was assessed by ANCOVA. All analyses were considered significant with $p<0.05$. Stata software (version 13; StataCorp LP, College Station, TX, USA) was used for statistical processing.

\section{Results}

Characteristics of the subjects and allelic frequencies in each methylated population

The background and distribution of genotypes of the subjects, including $\mathrm{CpG}$ island methylation status of each of the four genes, are shown in Table 2. In the 510 subjects, the distribution for the $D N M T 3 A$ variants was as follows: rs6733868: $C C=212, C G=224$, and $G G=74$; rs13428812: $\mathrm{AA}=313, \mathrm{AG}=166$, and $\mathrm{GG}=31$, both meeting Hardy-Weinberg equilibrium $(p=0.25$ and $p=$ 0.16 , respectively), and these distributions did not differ from the data reported by HapMap-JPT ( $p=0.51$ and $p=0.20$, respectively). The CpG methylated subjects for the genes $\left(p 14^{A R F}, p 16^{I N K 4 a}, D A P K\right.$, and $\left.C D H 1\right)$ were $167,134,252$, and 192, respectively. The mean age in the $p 14^{A R F}$-methylated group was significantly higher than that in the unmethylated group, whereas no significant difference was found in the other three genes. The male/female ratio was not significantly different among methylated and unmethylated groups in all four genes.

Table 1 Primer sets used for methylation-specific polymerase chain reaction

\begin{tabular}{|c|c|c|c|}
\hline gene name & methylated forward & methylated reverse & product size \\
\hline$\overline{p 14^{A R F}}$ & 5'-gtgttaaagggcggcgtagc-3' & 5'-aaaaccctcactcgcgacga-3' & $122 \mathrm{bp}$ \\
\hline$p 16^{\text {INK4a }}$ & 5'-ttattagagggtggggcggatcgc-3' & 5'-gaccccgaaccgcgaccgtaa-3' & $150 \mathrm{bp}$ \\
\hline DAPK & 5'-ggatagtcggatcgagttaacgtc-3' & 5'-ccctcccaaacgecga-3' & $98 \mathrm{bp}$ \\
\hline \multirow[t]{2}{*}{$\mathrm{CDH} 1$} & 5'- ttaggttagagggttatcgcgt-3' & 5'-taactaaaaattcacctaccgac-3' & $115 \mathrm{bp}$ \\
\hline & unmethylated forward & unmethylated reverse & \\
\hline$p 14^{A R F}$ & 5'-ttttggtgttaaagggtggtgtagt-3' & 5'-cacaaaaaccctcactcacaacaa-3' & $132 \mathrm{bp}$ \\
\hline$p 16^{\text {INK4a }}$ & 5'-ttattagagggtggggtggattgt-3' & 5'-caaccccaaaccacaaccataa-3' & $151 \mathrm{bp}$ \\
\hline DAPK & 5'-ggaggatagttggattgagttaatgtt-3' & 5'-caaatccctcccaaacaccaa-3' & $106 \mathrm{bp}$ \\
\hline $\mathrm{CDH} 1$ & 5'- taattttaggttagagggttattgt-3' & 5'-cacaaccaatcaacaacaca-3' & 97 bp \\
\hline
\end{tabular}


Table 2 Characteristics of the subjects and allelic frequency in $\mathrm{CpG}$ methylated population of each genes

\begin{tabular}{|c|c|c|c|c|c|}
\hline & overall & $p 14^{A R F_{-M}}$ & $p 16^{I N K 4 a}-\mathrm{M}$ & DAPK-M & $\mathrm{CDH1-M}$ \\
\hline number of sample & 510 & 167 & 134 & 252 & 192 \\
\hline mean age $\pm S D$ & $60.5 \pm 13.7$ & $62.9 \pm 13.7^{\mathrm{a}}$ & $61.2 \pm 11.8$ & $61.5 \pm 13.6$ & $60.3 \pm 13.0$ \\
\hline male: female & 297: 213 & 91: 76 & 78: 56 & 150: 102 & $117: 75$ \\
\hline HP infection status & $321 / 510$ & $117 / 167^{b}$ & $111 / 134^{c}$ & $186 / 252^{c}$ & $148 / 192^{c}$ \\
\hline \multicolumn{6}{|l|}{ (rs6733868 C > G) } \\
\hline CC & 212 & $81^{d}$ & $69^{e}$ & $122^{f}$ & $100^{9}$ \\
\hline$C G$ & 224 & 61 & 49 & $112^{c}$ & 70 \\
\hline GG & 74 & 25 & 16 & 18 & 22 \\
\hline G allele freqency & $36.5 \%$ & $33.2 \%$ & $30.2 \%^{h}$ & $29.4 \%^{c}$ & $29.7 \%^{i}$ \\
\hline \multicolumn{6}{|l|}{$(\mathrm{rs} 13428812 \mathrm{~A}>\mathrm{G})$} \\
\hline $\mathrm{AA}$ & 313 & 111 & $97^{j}$ & $169^{k}$ & $145^{c}$ \\
\hline$A G$ & 166 & 47 & 28 & 73 & 37 \\
\hline GG & 31 & 9 & 9 & 10 & 10 \\
\hline $\mathrm{G}$ allele freqency & $22.4 \%$ & $19.5 \%$ & $17.2 \%^{\prime}$ & $18.5 \%^{m}$ & $14.8 \%^{\mathrm{c}}$ \\
\hline
\end{tabular}

$-M$ Methylated

a: $p=0.0046, \mathrm{~b}: p=0.019, \mathrm{c}: p<0.0001, \mathrm{~d}: p=0.028, \mathrm{e}: p=0.0079, \mathrm{f}: p=0.0022, \mathrm{~g}: p=0.0002, \mathrm{~h}: p=0.015, \mathrm{i}: p=0.0005$,

$\mathrm{j}: p=0.0027, \mathrm{k}: p=0.011, \mathrm{l}: p=0.017, \mathrm{~m}: p=0.0034 \mathrm{vs}$. unmathylated group of each gene

The ratio of HP positivity was significantly higher in the methylated group than in the unmethylated group in all four genes. In both gene polymorphisms, the minor allele frequency in the methylated groups tended to be lower.

\section{Association between DNMT3A polymorphisms and CpG hypermethylation of each gene}

For the polymorphism rs6733868, the methylation of all four genes under study $\left(p 14^{A R F}, p 16^{I N K 4 a}, D A P K\right.$, and $C D H 1)$ showed significant involvement as revealed by regression analysis using a dominant genetic model adjusted for sex, age, and HP infection status (Table 3). In addition, a recessive genetic model also showed the significant involvement of DAPK methylation. For the polymorphism rs13428812, the dominant genetic model showed a significant association with methylation in three genes, all except $p 14^{A R F}$. In contrast, the recessive genetic model showed no significant involvement of methylation in any of the four genes (Table 4).

Table 3 Association between DNMT3A rs6733868 and CpG methylation of each genes

\begin{tabular}{|c|c|c|c|c|}
\hline genotype & p14 ${ }^{A R F}-U M(343)$ & $p 14^{A R F}-M(167)$ & adjusted $\mathrm{OR}^{*}(95 \% \mathrm{Cl}) ; p$ value & \\
\hline CC & 131 & 81 & reference & reference \\
\hline CG & 163 & 61 & & $0.67(0.46-0.98) ; 0.038$ \\
\hline GG & 49 & 25 & $1.07(0.629-1.82) ; 0.80$ & \\
\hline genotype & p16 INK4a-UM (376) & p16 $6^{\text {INK4a }}-M(134)$ & adjusted $\mathrm{OR}^{*}(95 \% \mathrm{Cl}) ; p$ value & \\
\hline CC & 143 & 69 & reference & reference \\
\hline CG & 175 & 49 & & $0.60(0.40-0.91) ; 0.015$ \\
\hline GG & 58 & 16 & $0.78(0.42-1.44) ; 0.42$ & \\
\hline genotype & DAPK-UM (258) & DAPK-M (252) & adjusted $\mathrm{OR}^{*}(95 \% \mathrm{Cl}) ; p$ value & \\
\hline CC & 90 & 122 & reference & reference \\
\hline CG & 112 & 112 & & $0.59(0.41-0.85) ; 0.0050$ \\
\hline GG & 56 & 18 & $0.28(0.15-0.49) ;<0.0001$ & \\
\hline genotype & CDH1-UM (318) & CDH1-M (192) & adjusted $\mathrm{OR}^{*}(95 \% \mathrm{Cl}) ; p$ value & \\
\hline CC & 112 & 100 & refernce & reference \\
\hline CG & 154 & 70 & & $0.52(0.36-0.75) ; 0.0005$ \\
\hline GG & 52 & 22 & $0.70(0.40-1.20) ; 0.19$ & \\
\hline
\end{tabular}

-UM: unmethylated; -M: methylated

*: adjusted for gender, age and HP infection status 
Table 4 Association between DNMT3A rs13428812 and CpG methylation of each genes

\begin{tabular}{|c|c|c|c|c|}
\hline genotype & p14 ARF-UM (343) & $p 14^{A R F}-\mathrm{M}(167)$ & adjusted $\mathrm{OR}^{*}(95 \% \mathrm{Cl}) ; p$ value & \\
\hline AA & 202 & 111 & reference & reference \\
\hline$A G$ & 119 & 47 & & $0.77(0.52-1.14) ; 0.19$ \\
\hline GG & 22 & 9 & $0.93(0.41-2.10) ; 0.87$ & \\
\hline genotype & p16 INK4a $_{\text {UMM (376) }}$ & p16 $6^{I N K 4 a}-M(134)$ & adjusted $\mathrm{OR}^{*}(95 \% \mathrm{Cl}) ; p$ value & \\
\hline AA & 216 & 97 & reference & reference \\
\hline$A G$ & 138 & 28 & & $0.55(0.35-0.85) ; 0.0078$ \\
\hline GG & 22 & 9 & $1.44(0.62-3.37) ; 0.40$ & \\
\hline genotype & DAPK-UM (258) & DAPK-M (252) & adjusted $O R^{*}(95 \% C l) ; p$ value & \\
\hline AA & 144 & 169 & reference & reference \\
\hline$A G$ & 93 & 73 & & $0.66(0.46-0.96) ; 0.030$ \\
\hline GG & 21 & 10 & $0.53(0.240-1.17) ; 0.12$ & \\
\hline genotype & CDH1-UM (318) & CDH1-M (192) & adjusted $O R^{*}(95 \% C l) ; p$ value & \\
\hline AA & 168 & 145 & reference & reference \\
\hline$A G$ & 129 & 37 & & $0.37(0.25-0.56) ;<0.0001$ \\
\hline GG & 21 & 10 & $0.90(0.40-2.00) ; 0.79$ & \\
\hline
\end{tabular}

-UM Unmethylated; $-M$ Methylated

*: adjusted for gender, age and HP infection status

\section{Characteristics and allelic frequencies of the subjects by the number of methylations per gene}

The distribution of background and genotype according to the number of methylations among the four genes were compared with a reference group (without methylated genes) (Table 5). The mean age of subjects tended to be significantly higher in those with methylated genes among the four genes selected for this study. Also, the rate of HP infection increased with the number of methylated genes and was considerably higher for all degrees of methylation. In addition, HP positivity was significantly correlated with the increased number of methylated genes $(p<0.0001$ by ANCOVA). For the polymorphism rs6733868, the frequency of the $\mathrm{CC}$ genotype was significantly higher in the methylated group; conversely, the frequency of the GG genotype was lower, and the frequency of the minor allele tended to decrease with the number of methylated genes. Similarly, for the polymorphism rs13428812, the AA genotype tended to be significantly more frequent in the methylated group, while the GG genotype was less frequent, and the minor allele frequency tended to decrease with the number of methylated genes. An inverse correlation between minor allele number for both polymorphisms (rs6733868 and 13,428,812) and the number of CpG methylated genes was found (Fig. 1).

\section{Association between DNMT3A polymorphisms and the number of methylated genes}

We performed regression analysis using a dominant genetic model adjusted for sex, age, and HP infection status in three groups: a non-CIHM group without methylated genes, a low-CIHM group with one or two methylated genes, and a
high-CIHM high with three or more methylated genes (Table 6). For the polymorphism rs6733868, carrying the minor allele was significantly associated with a low risk of methylation in both the low-CIHM and high-CIHM groups compared with the non-CIHM group. By comparing the low- and high-CIHM groups, a significant association was observed for carriers of the minor allele with a reduced risk of methylation. Similar results were also obtained with the rs13428812 polymorphism.

In 321 ( $n=510 ; 62.9 \%)$ HP-infected subjects, no significant association was noted with gene polymorphisms regarding methylation in the low-CIHM and non-CIHM groups (Table 6). In contrast, there was a strong and significant association in the high-CIHM group, indicating that carrying the minor allele for both gene polymorphisms (rs6733868 and rs13428812) was associated with a significant suppression of high-frequency CpG methylation.

\section{Discussion}

DNMTs play an important role in DNA methylation and establish methylation patterns on $\mathrm{CpG}$ islands. Among the DNMTs, DNMT3a has a greater effect on de novo methylation than DNMT3b [8]. We previously demonstrated that DNMT3A polymorphisms (rs6733868 and rs13428812) are associated with the severity of gastric mucosal atrophy, which is accompanied by chronic inflammation and the subsequent development of gastric cancer [22]. However, whether these polymorphisms affect $\mathrm{CpG}$ island methylation as a precancerous condition has not been revealed. In this study, we examined whether either gene polymorphism was associated with the accumulation of methylation of $\mathrm{CpG}$ islands in the 
Table 5 Characteristics and allelic frequency of the subjects by number of methylated genes

\begin{tabular}{|c|c|c|c|c|c|}
\hline number of methylated gene & 0 & 1 & 2 & 3 & 4 \\
\hline number of sample & 123 & 156 & 131 & 75 & 25 \\
\hline mean age $\pm S D$ & $59.8 \pm 14.9$ & $59.9 \pm 13.3$ & $59.5 \pm 14.1$ & $61.9 \pm 12.3$ & $68.2 \pm 10.3^{\mathrm{a}}$ \\
\hline male: female & 66: 57 & 100: 56 & $71: 60$ & 46: 29 & 14: 11 \\
\hline HP infection status & $53 / 123$ & $89 / 156^{\mathrm{b}}$ & $89 / 131^{c}$ & $67 / 75^{c}$ & $23 / 25^{c}$ \\
\hline \multicolumn{6}{|l|}{ (rs6733868 C > G) } \\
\hline CC & 36 & 56 & $61^{d}$ & $44^{c}$ & $15^{\mathrm{e}}$ \\
\hline CG & 57 & 82 & 53 & 24 & 8 \\
\hline GG & 30 & $18^{f}$ & $17^{9}$ & $7^{\mathrm{h}}$ & 2 \\
\hline G allele freuqency & $47.6 \%$ & $37.8 \%^{i}$ & $33.2 \%$ & $25.3 \%^{c}$ & $24.0 \%^{k}$ \\
\hline \multicolumn{6}{|l|}{$(\mathrm{rs} 13428812 \mathrm{~A}>\mathrm{G})$} \\
\hline$A A$ & 57 & $93^{1}$ & $82^{\mathrm{m}}$ & $61^{c}$ & $20^{n}$ \\
\hline$A G$ & 53 & 57 & 43 & 10 & 3 \\
\hline GG & 13 & $6^{\circ}$ & 6 & 4 & 2 \\
\hline G allele frequency & $32.1 \%$ & $22.1 \%^{p}$ & $21.0 \%^{\mathrm{q}}$ & $12.0 \%^{\mathrm{c}}$ & $14.0 \%^{r}$ \\
\hline
\end{tabular}

a: $p=0.0082, \mathrm{~b}: p=0.016$, c: $p<0.0001$, d: $p=0.0065$, e: $p=0.0051, \mathrm{f}: p=0.0063, \mathrm{~g}: p=0.023, \mathrm{~h}: p=0.0085$,

$\mathrm{i}: p=0.025, \mathrm{j}: p=0.0011, \mathrm{k}: p=0.0027, \mathrm{l}: p=0.030, \mathrm{~m}: p=0.012, \mathrm{n}: p=0.0021, \mathrm{o}: p=0.032, \mathrm{p}: p=0.0091$,

$\mathrm{q}: p=0.0048, \mathrm{r}: p=0.010$ vs. 0 group

gastric mucosa. The results showed that the minor allele frequencies of rs6733868 (C > G) and rs13428812 (A > G) were significantly reduced as the number of methylations of the CpG islands of the four genes examined increased. Consistent with the fact that $\mathrm{CpG}$ methylation accumulates during inflammation and aging, we observed an increase in older subjects and with HP infection rates as the number of methylated CpGs increased in our study population. However, regression analysis after adjustment for confounding factors showed a strong and significant association of both gene variants, suggesting that DNMT3A gene polymorphism is an independent factor in the accumulation of methylation of gastric mucosal $\mathrm{CpG}$ islands of the studied genes. Although the DNMT3A polymorphism has been reported to be associated with gastric cancer, HP infection, and gastric mucosal atrophy $[16,22,23]$, its association with methylation of gastric mucosa genes has not been clear. Our current study has revealed this association for the first time.

To assess the degree of $\mathrm{CpG}$ island methylation, we selected the CpG sites of four genes $\left(p 14^{A R F}, p 16^{I N K 4 a}\right.$, $D A P K$, and $C D H 1$ ), because we previously reported that increased $\mathrm{CpG}$ island hypermethylation in these four genes of the non-neoplastic gastric mucosa correlates
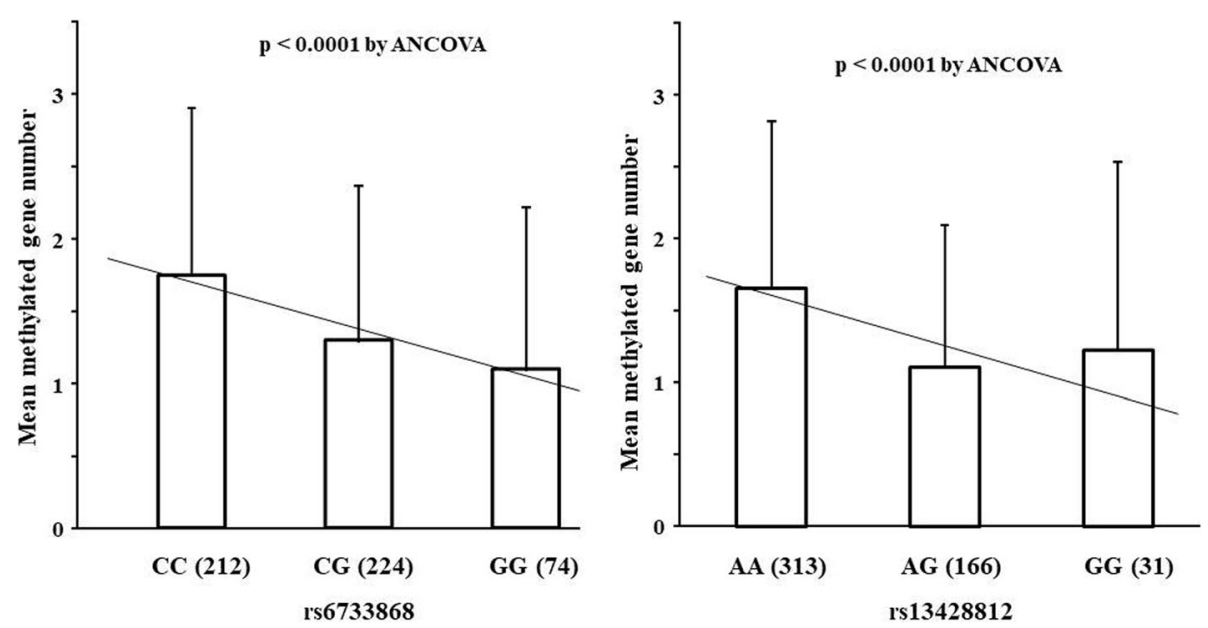

Fig. 1 Correlation of genotypes with the number of genes with $\mathrm{CpG}$ methylation. There was a significant inverse correlation between minor allele number of both polymorphisms (rs6733868 and 13,428,812) and the number of genes with CpG methylation ( $p<0.0001$ by ANCOVA) 
Table 6 Association between DNMT3A polymorphisms and number of methylated genes in the whole population and in patients infected with HP

\begin{tabular}{|c|c|c|c|c|c|c|c|c|}
\hline \multirow[b]{3}{*}{ rs6733868 } & \multicolumn{4}{|c|}{ Whole population } & \multicolumn{4}{|c|}{ Patients infected with HP } \\
\hline & \multicolumn{3}{|c|}{ Allelic variants } & \multirow[t]{2}{*}{ OR (95\% C.I.); $p$ value } & \multicolumn{3}{|c|}{ Allelic variants } & \multirow[t]{2}{*}{ OR (95\% C.I.); $p$ value } \\
\hline & CC & CG & GG & & $\mathrm{CC}$ & CG & GG & \\
\hline \multicolumn{9}{|c|}{ number of methylated genes } \\
\hline $0(123)$ & 36 & 57 & 30 & reference & 17 & 22 & 14 & reference \\
\hline 1 or 2 (287) & 117 & 135 & 35 & $0.59(0.37-0.94) ; p=0.026$ & 69 & 89 & 20 & $0.74(0.38-1.42) ; p=0.36$ \\
\hline \multirow[t]{2}{*}{3 or $4(100)$} & 59 & 32 & 9 & $0.34(0.18-0.64) ; p<0.0001$ & 56 & 26 & 8 & $0.26(0.12-0.55) ; p=0.0004$ \\
\hline & \multicolumn{3}{|c|}{ Allelic variants } & OR (95\% C.I.); $p$ value & \multicolumn{3}{|c|}{ Allelic variants } & OR (95\% C.I.); $p$ value \\
\hline rs13428812 & $\mathrm{AA}$ & AG & GG & & $\mathrm{AA}$ & AG & GG & \\
\hline \multicolumn{9}{|c|}{ number of methylated genes } \\
\hline $0(123)$ & 57 & 53 & 13 & reference & 26 & 21 & 6 & reference \\
\hline 1 or 2 (287) & 175 & 100 & 12 & $0.55(0.36-0.85) ; p=0.0073$ & 107 & 67 & 4 & $0.61(0.32-1.13) ; p=0.12$ \\
\hline 3 or $4(100)$ & 81 & 13 & 6 & $0.22(0.11-0.44) ; p<0.0001$ & 74 & 11 & 5 & $0.18(0.083-0.41) ; p<0.0001$ \\
\hline
\end{tabular}

by logistic regression analysis after adjustment for age, gender and HP infection status

(): number of subjects

with a higher risk of gastric cancer [21]. The $14^{\mathrm{ARF}}$ and p16 ${ }^{\mathrm{INK} 4 \mathrm{a}}$ proteins are encoded by CDKN2A; these proteins act on the p53 and pRb pathways, respectively, to negatively regulate the cell cycle $[19,20]$. The loss of function due to methylation or deletion of CDKN2A has been observed in many cancers [24]. Additionally, the importance of $D A P K$ and $C D H 1$ in cancer has been revealed $[25,26]$. Because these four genes play an important role in carcinogenesis, we could not exclude the possibility that methylation of these genes renders them silent, and hence, directly contributes to carcinogenesis. Nonetheless, since many reports describe CpG methylation of these genes in non-neoplastic areas [18, 21, 27], it is unlikely that their methylation contributes directly to carcinogenesis.

Global DNA methylation patterns in human cancer are altered by hypermethylation of the $\mathrm{CpG}$ islands and hypomethylation of the non-CpG parts [28]. The de novo DNMTs have also been implicated in this dynamic methylation early in tumor development [29]. We presumed that the methylation of these gene groups reflects the degree of change in global DNA methylation patterns, as they are confirmed to undergo methylation from the precancerous lesion stage. In the stomach, CIHM is associated with HP infection [7, 8, 17], the degree of gastritis [18], and the risk of carcinogenesis [23, 27]. Additionally, de novo DNMT expression is more highly enhanced in tumor and corneal tumor areas than in non-tumor areas [12]. These previous reports suggest that HP infection could induce de novo synthesis of DNMT genes in the stomach, with the subsequent methylation of CpG islands in genes, which in turn leads to carcinogenesis. In our current findings, the rate of $\mathrm{HP}$ infection increased with the increasing number of $\mathrm{CpG}$ methylated genes, and a significant relationship between both rs6733868 and rs13428812 gene polymorphisms and the number of $\mathrm{CpG}$ methylations was found only in the HP-infected subjects, but not in HP-uninfected subjects (data not shown). Notably, genetic polymorphisms are not the only regulators of protein expression. These gene polymorphisms might be of significance when there is an inducement by HP infection and the induction of gene expression triggered in DNMTs. However, HP infection does not directly induce DNMT mRNA [27]. Hmadcha et al. reported that the increase in DNMT activity by IL- $1 \beta$ is mediated by reactive oxygen species and nitric oxide [30]. Thus, it is likely that HP infection might have induced de novo DNMTs through this system, leading to methylation of CpG. Considering our results that minor alleles carrying the rs6733868 and rs13428812 gene polymorphisms correlated negatively with the accumulation of $\mathrm{CpG}$ methylation, we infer that these two types of gene polymorphisms are decreasing functional types.

There are several clinical limitations in this study. First, it was a retrospective study using samples collected at a single institution in Japan. The genetic polymorphisms examined in this study population satisfy the Hardy-Weinberg equilibrium, and the distribution of the genotypes is similar to that reported in the HapMapJPT, which indicates that the population distribution is typical of Japanese citizens. However, a follow-up examination at another institution would be necessary. Second, there is no assurance that the validity of the four selected CpG gene sites studied represents changes in global DNA methylation patterns. Thus, based on the methylation status of $\mathrm{CpG}$, the possibility of more methylation occurring at an earlier stage should be 
investigated. Finally, it is unclear how the genetic polymorphisms examined in this study might indeed affect the expression and function of DNMT3a protein. Fan et al. reported that rs1550117, an A > G variant in the $D N M T 3 A$ gene promoter, affects protein expression and elevates DNMT3a expression, leading to the development of gastric cancer [31]. Therefore, we deduced that the minor alleles of the gene polymorphisms examined in this study might be of a hypofunctional type, but confirmation is required at the experimental level.

\section{Conclusions}

Our study indicates that the polymorphisms of DNMT3A are associated with the accumulation of gene methylation in gastric mucosa. Carrying the minor allele of rs6733868 or rs13428812 inhibits aberrant gene methylations, especially under conditions of HP infection.

\section{Abbreviations}

HP: Helicobacter pylori; DNMT: DNA methyltransferase; CIHM: CpG island hyper methylations; DAPK: Death-associated protein kinase; $\mathrm{CDH}$ : E-cadherin; PCR-SSCP: Polymerase chain reaction-single-strand conformation polymorphism; MSP: Methylation-specific PCR; UV: Ultraviolet; SD: Standard deviation; OR: Odds ratio; Cl: Confidence interval; CDKN2A: Cyclin dependent kinase inhibitor $2 \mathrm{~A}$

\section{Acknowledgments}

We would like to thank Prof. Yasuhito Ishigaki for proofreading this manuscript.

\section{Authors' contributions}

TH determined the genotypes, analyzed the data, and wrote the paper. TA was responsible for supervising the scientific research and writing the manuscript. MN, TO, NS, HT, MO, TN-H, RH, and TS2 contributed to the literature review; data analysis; drafting, editing, and critical revision of the manuscript; and approval of the final version of the manuscript. TT and TS1 obtained the clinical samples and data, and participated in the design of the study. All authors have read and approved the final manuscript.

\section{Funding}

No funding was received.

\section{Availability of data and materials}

All data generated during this study are included in this published article. The raw data analyzed during the current study are not publicly available due to risk of compromising individual privacy. The application and the written consent forms state that the data will only be available to the researchers within the project. For inquires on the data, researchers should first contact the owner of the database, Fujita Health University. Please contact the corresponding author with requests and for assistance with data requests.

\section{Ethics approval and consent to participate}

The Ethics Committees of Fujita Health University approved the protocol (HM18-094), and all participants gave their written informed consent.

\section{Consent for publication}

Not applicable.

\section{Competing interests}

The authors declare that they have no competing interests.

\section{Author details}

'Department of Gastroenterology, Kanazawa Medical University, 1-1 Daigaku, Uchinada-machi, Ishikawa 920-0293, Japan. '2Department of Gastroenterology, Fujita Health University, 1-98 Dengakugakubo, Kutsukake-cho, Toyoake 470-1192, Japan. ${ }^{3}$ Department of Gastroenterology and Hepatology, Kansai Medical University, 2-5-1 Shin-machi, Hirakata, Osaka 573-1010, Japan.
Received: 29 June 2020 Accepted: 8 October 2020

Published online: 16 October 2020

\section{References}

1. Arnold M, Abnet CC, Neale RE, Vignat J, Giovannucci EL, McGlynn KA, et al. Global Burden of 5 Major Types Of Gastrointestinal Cancer. Gastroenterology. 2020;159:335-349.e15.

2. Parsonnet J, Friedman GD, Vandersteen DP, Chang Y, Vogelman JH, Orentreich $\mathrm{N}$, et al. Helicobacter pylori infection and the risk of gastric carcinoma. N Engl J Med. 1991;325:1127-31.

3. Huang JQ, Sridhar $S$, Chen Y, Hunt RH. Meta-analysis of the relationship between helicobacter pylori seropositivity and gastric cancer. Gastroenterology. 1998;114:1169-79.

4. Ozasa K, Kurata JH, Higashi A, Hayashi K, Inokuchi H, Miki K, et al. Helicobacter pylori infection and atrophic gastritis: a nested case-control study in a rural town in Japan. Dig Dis Sci. 1999;44:253-6.

5. Correa P. Human gastric carcinogenesis: a multistep and multifactorial process--first American Cancer Society award lecture on Cancer epidemiology and prevention. Cancer Res. 1992;52:6735-40.

6. Uemura N, Okamoto S, Yamamoto S, Matsumura N, Yamaguchi S, Yamakido $M$, et al. Helicobacter pylori infection and the development of gastric cancer. N Engl J Med. 2001;345:784-9.

7. Maekita T, Nakazawa K, Mihara M, Nakajima T, Yanaoka K, lguchi M, et al. High levels of aberrant DNA methylation in helicobacter pylori-infected gastric mucosae and its possible association with gastric cancer risk. Clin Cancer Res. 2006:12:989-95.

8. Tahara T, Arisawa T, Shibata T, Wang FY, Nakamura M, Sakata M, et al. Risk prediction of gastric cancer by analysis of aberrant DNA methylation in non-neoplastic gastric epithelium. Digestion. 2007;75:54-61.

9. Esteller M, Corn PG, Baylin SB, Herman JG. A gene hypermethylation profile of human cancer. Cancer Res. 2001;61:3225-9.

10. Sapari NS, Loh M, Vaithilingam A, Soong R. Clinical potential of DNA methylation in gastric cancer: a meta-analysis. PLoS One. 2012;7:e36275.

11. Li E. Chromatin modification and epigenetic reprogramming in mammalian development. Nat Rev Genet. 2002:3:662-73.

12. Ding WJ, Fang JY, Chen XY, Peng YS. The expression and clinical significance of DNA methyltransferase proteins in human gastric cancer. Dig Dis Sci. 2008;53:2083-9.

13. El-Omar EM, Carrington M, Chow WH, McColl KE, Bream JH, Young HA, et al Interleukin-1 polymorphisms associated with increased risk of gastric cancer. Nature. 2000:404(6776):398-402.

14. Arisawa T, Tahara T, Shibata T, Nagasaka M, Nakamura M, Kamiya Y, et al. Functional promoter polymorphisms of the macrophage migration inhibitory factor gene in gastric carcinogenesis. Oncol Rep. 2008;19:223-8.

15. Shibata T, Tahara T, Hirata I, Arisawa T. Genetic polymorphism of interleukin17A and -17F genes in gastric carcinogenesis. Hum Immunol. 2009;70:547-51.

16. Li H, Li W, Liu S, Zong S, Wang W, Ren J, et al. DNMT1, DNMT3A and DNMT3B polymorphisms associated with gastric cancer risk: a systematic review and meta-analysis. EBioMedicine. 2016;13:125-31.

17. Chan AO, Peng JZ, Lam SK, Lai KC, Yuen MF, Cheung HK, et al. Promoter methylation of E-cadherin gene in gastric mucosa associated with helicobacter pylori infection and in gastric cancer. Gut. 2003:52:502-6.

18. Tahara T, Arisawa T, Shibata T, Nakamura M, Yoshioka D, Okubo M, et al. Increased number of methylated CpG islands correlates with helicobacter pylori infection, histological and serological severity of chronic gastritis. Eur J Gastroenterol Hepatol. 2009:21:613-9.

19. Rizos H, Darmanian AP, Mann GJ, Kefford RF. Two arginine rich domains in the p14ARF tumour suppressor mediate nucleolar localization. Oncogene. 2000;19:2978-85.

20. Tannapfel A, Busse C, Weinans L, Benicke M, Katalinic A, Geissler F, et al. INK4a-ARF alterations and p53 mutations in hepatocellular carcinomas. Oncogene. 2001;20:7104-9.

21. Tahara T, Shibata T, Nakamura M, Yamashita H, Yoshioka D, Okubo M, et al. Increased number of CpG island hypermethylation in tumor suppressor genes of non-neoplastic gastric mucosa correlates with higher risk of gastric cancer. Digestion. 2010;82:27-36.

22. Jing W, Otsuka T, Nakamura M, Sakurai N, Takano H, Hayashi T, et al. Association of genetic polymorphisms in DNMT3A with the progression of gastric mucosal atrophy and susceptibility to gastric cancer in Japan. Oncol Lett. 2019;17:3482-8. 
23. Tahara T, Shibata T, Nakamura M, Okubo M, Yamashita H, Yoshioka D, et al. Polymorphisms of DNA repair and xenobiotic genes predispose to CpG island methylation in non-neoplastic gastric mucosa. Helicobacter. 2011;16: 99-106.

24. Poi MJ, Knobloch TJ, Li J. Deletion of RDINK4/ARF enhancer: a novel mutation to "inactivate" the INK4-ARF locus. DNA Repair. 2017;57:50-5.

25. Gozuacik D, Kimchi A. DAPk protein family and cancer. Autophagy. 2006;2: 74-9.

26. Shenoy S. CDH1 (E-cadherin) mutation and gastric Cancer: genetics, molecular mechanisms and guidelines for management. Cancer Manag Res. 2019;11:10477-86.

27. Kaise M, Yamasaki T, Yonezawa J, Miwa J, Ohta Y, Tajiri H. CpG island hypermethylation of tumor-suppressor genes in $\mathrm{H}$ pylori-infected nonneoplastic gastric mucosa is linked with gastric cancer risk. Helicobacter. 2008:13:35-41

28. Li W, Chen BF. Aberrant DNA methylation in human cancers. J Huazhong Univ Sci Technolog Med Sci. 2013;33:798-804.

29. Fernandez AF, Assenov Y, Martin-Subero Jl, Balint B, Siebert R, Taniguchi H, et al. A DNA methylation fingerprint of 1628 human samples. Genome Res. 2012;22:407-19.

30. Hmadcha A, Bedoya FJ, Sobrino F, Pintado E. Methylation-dependent gene silencing induced by interleukin 1 beta via nitric oxide production. J Exp Med. 1999;190:1595-604

31. Fan H, Liu D, Qiu X, Qiao F, Wu Q, Su X, et al. A functional polymorphism in the DNA methyltransferase-3A promoter modifies the susceptibility in gastric cancer but not in esophageal carcinoma. BMC Med. 2010;8:12.

\section{Publisher's Note}

Springer Nature remains neutral with regard to jurisdictional claims in published maps and institutional affiliations.

Ready to submit your research? Choose BMC and benefit from:

- fast, convenient online submission

- thorough peer review by experienced researchers in your field

- rapid publication on acceptance

- support for research data, including large and complex data types

- gold Open Access which fosters wider collaboration and increased citations

- maximum visibility for your research: over $100 \mathrm{M}$ website views per year

At BMC, research is always in progress.

Learn more biomedcentral.com/submissions 